\title{
LIST OF COLEOPTERA.
}

TAKEN AT GRIMSEY, ONTARIO, BY J. PETTIT.

(Continued from page $1 \mathrm{I} 8$.)

SPHINDID $E$.

*Sphindus Americanus, Lec. CIOIDÆ.

${ }^{*}$ Cis fuscipes, Mellie.

*Ennearthron mellyi, Mell.

*Ceracis militaris, Mell.

TENEBRIONID $Æ$.

Phellopsis obcordata, Lec.

Blapstinus metallicus, Lec.

Centronopus calcaratus, Fab.

*Merinus lævis, Oliv.

Xylopinus saperdoides, Oliv.

Haplandus femoratus, $F a b$.

$$
\text { *concolor, Lec. }
$$

Nyctobates Pensylvanica, De Geer.

*Iphthinus opacus, Lec.

Tenebrio molitor, Linn. castaneus, Knoch. tenebrioides, Beauv.

Paratenetus punctatus, Spin.

*Tribolium madens, Charp.

Uloma impressa, Mels.

*culinaris, Linn.

*mentalis, Horn.

Boletotherus cornutus, Fab.

Boletophagus corticola, Say.

*Rhipidandrus flabellicornis, $L e c$.

*Pentayhyllus pallidus, Lec.

Diaperis hydni, Fab.

Haplocephala bicornis, Oliv.

Platydema excavatum, $D e j$. Americanum, Lap. *picilabrum, Mels. flavipes, Fab.
Hypophloeus parallelus, Mels.

*thoracicus, Mels.

*Diœdus punctatus, Lec.

Helops micans, $F a b$.

Meracantha contracta, Beauv.

*Strongylium tenuicolle, Say. CISTELID $Æ$.

Allecula nigrans, $M$ els.

*Hymenorus obscurus, Say. niger, Mels.

Cistela brevis, Say. sericea, Say.

Isomira quadristriata, Couper. *velutina, $L e c$.

* Mycetocharis foveatus, $L e c$.

*tenuis, Lec.

binotata, Say.

*Chromatia amœna, Say.

Capnochroa fuliginosa, $M e l s$.

Androchirus luteipes, Lec.

$$
\text { LAGRIIDÆ. }
$$

Arthromacra, aenea, Say. PYROCHROIDA.

Pyrochroa flabellata, $F a b$.

femoralis, $L e c$.

Schizotus cervicalis, Nezw.

Dendroides concolor, Nezum. Canadensis, Latr. ANTHICID $Æ$.

*Corphyra collaris, Say. lugubris, Say. newmani, Lec.

Notoxus anchora, Hentz.

*Anthicus obscurus, Ferte.

\footnotetext{
* Species marlied with an asterisk have not been included in the list of Canadian Coleoptera.
}

IThree specimens taken by Dr. Milward. 
Anthicus formicarius, Ferte. *floralis, Payk. scabriceps, Lec. cervinus, Ferte.

*coracinus, Lec.

*Xylophilus piceus, Lec. *fasciatus, Mels.

MELANDRYID $A$.

*Cænifa pallipes, Mels.

Tetratoma truncorum, Lec.

Stenotrachelus arctatus, Say. ${ }^{2}$

Penthe obliquata, $F a b$. pimelia, Fab.

Synchroa punctata, Nerom.

Emmesa connectens, Newm.

Melandrya striata, Say.

*Xylita lævigata, Hel.

Spilotes quadripustulosus, Mels.

Hypulus simulator, Newm.

Serropalpus striatus, Hel.

Enchodes sericea, Hald.

Dircæa liturata, Lec.

*Symphora flavicollis, Hald. * rugosa, Hald.

Hallomenus scapularis, Mels.

Eustrophus bicolor, Fab. bifasciatus, Say. tomentosus, Say.

Orchesia gracilis, Mels.

\section{MORDELLID $A$}

*Anaspis nigra, Hald. flavipennis, Hald. rufa, Say.

* Tomoxia inclusa, Lec.

Mordella melæna, Lec. scutellaris, $F a b$.

*octopunctatus, Fab. marginata, Mels.
Mordella lineata, Mels.

* serval, Say. ${ }^{3}$

triloba, Say.

*Mordellistena lutea, Mels. ?

trifasciata, Say.

*limbalis, Mels.

*ornata, Mels.

scapularis, Say.

*tosta, Lec.

*varians, Lec.

*morula, Lec.

"unicolor. ${ }^{4}$

*divisa, Lec.

*liturata, Mels.

*discolor, Mels.

Pelecotoma flavipes, $M e l s$.

MELOID $Æ$.

Meloe angusticollis, Say.

Macrobasis Fabricii, Lec.

Epicauta Pensylvanica, $D e$ Geer. vittata, $D e j$.

CEPHALOID $Æ$.

Cephaloon lepturides, Nezm.

CEDEMERID $Æ$

Ascelera ruficollis, Say.

puncticollis, Say.

MYCTERID $\mathbb{A}$.

Mycterus scaber, Hald..$^{5}$

PYTHID $\approx$.

Pytho Americanus, Kirby. * strictus, Lec.

Boros unicolor, Say.

*Rhinosimus nitens, Lec.

SCOLYTIDA.

*Crypturgus atomus, Lec.

*Cryphalus fasciatus, Say.

*mali, Fitch

*materiarius, Fitch.

${ }^{2}$ A single specimen, taken on the Lake Shore. 3 Taken in the Township of Adelaide. 4Taken in Bosanquet. 


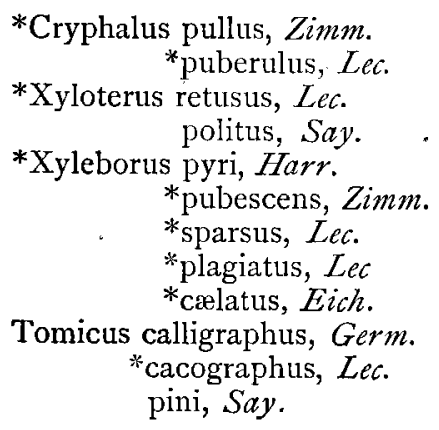

* Micracis suturalis, Lec.

*aculeatus, Lec.

*Chramesus hicoriæ, Lec.

*Phlorotribus limniaris, Harr.

Hylesinus aculeatus, Say.

*opaculus, Lec.

dentatus, Say.

Dendroctonus terebrans, Lec.

*simplex, Lec.

*Hylastes porculus, Er. pinifex, Fitch.

\section{MISCELLANEOUS NOTES.}

Rearing Butterflies from the EgG.-In the last number of the Canadian Entomologist I mentioned that I had succeeded in inducing females of P. ajax to deposit eggs, by enclosing them in a keg placed over the growing food-plant--the paw-paw. The first female enclosed on May i6th laid a number of eggs, and another female was enclosed in the same keg on the ${ }_{7} 7$ th. I was obliged to leave home for some days, and returned on June ist, when I found but six larvæ in the keg. These had hatched and attained a length of three-fourths of an inch within sixteen days. On the $5^{\text {th }}$ of June the larvæ were mature and had stopped feed. ing; the whole time from the laying of the eggs being but three weeks. On the 2 oth one 1 Marcellus emerged; on the 2 ist a 9 Marcellus, and by the 23 rd four others emerged, all Marcellus.

On the ist June I put three $q A j a x$ into another $\mathrm{keg}$; by the and 37 eggs were deposited. These began to hatch on the 6th. From this lot I obtained 24 chrysalids, which began to give imagos by 3 rd of July. From them I obtained $\mathrm{I} 2 \mathrm{~s}$ and $\mathrm{io}$ + , all Marcellus.

On June 7 th I shut up a $q$ Marcellus, the first I had noticed flying

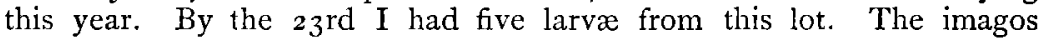
began to appear on the $4^{\text {th }}$ of July, and gave three $q$ and one $\delta$, all Marcellus, not distinguishable from those produced from the eggs of Ajax as above.

So that the question of the identity of Ajax and Marcellus may be regarded as settled.

I have had no difficulty, by some means, in induclng other species to deposit eggs. On a young tulip tree I placed two black females of Turnus (Glaucus), and have now several larva growing as the result. I have also raised two broods of $C$. Philodice, and the Nisoniades lycidas, and $N$.pylades, Scudder. 